\title{
Trophic evolution of a reservoir with overheated waters : nuclear power station at Cattenom, Moselle, East France
}

\author{
D. Vein! \\ M. Gigleux ${ }^{2}$ \\ A. Flesch ${ }^{2}$ \\ J.-F. Pierre ${ }^{3}$ \\ R. Marzou ${ }^{2}$ \\ J.-C. Pihan ${ }^{2}$
}

Keywords : Artificial lake, chemistry, overheated waters, hypertrophy.

The Mirgenbach reservoir (vol. : $7.3 \mathrm{Mm}^{3}$, area : $90 \mathrm{ha}$, mean depth : $7.7 \mathrm{~m}$ ) is a safety and thermal water buffer for the nuclear power station in Cattenom (Eastern France). Water used for cooling is pumped out of river Moselle, filtered, overheated, concentrated by evaporation in the atmospheric cooling towers that discharge the cooled water into this artificial lake where it continues to cool. The levels of temperature, conductivity, hardness and eutrophising capacities are higher than those of river Moselle waters. The hydrobiological study was conducted from April 1986 to December 1988. Before August 1986, the lake had developed to a dimictic stratified type. Immediately after the first input in August 1986, it developed towards a polymictic unstratified type. The oxygen levels, the conductivity, the $\mathrm{pH}$ and the temperature were homogeneous from surface to bottom everywhere in the reservoir at any time.

The trophic level study has enabled us to investigate the interrelationships between the physical and chemical factors, and the biocenoses in which the relationships between the various trophic levels could be observed. Considering the level of eutrophication and the amoun of biomass produced, exploitation of the algal and fish productions was proposed. Applied studies are planned : the aquaculture of the green alga Hydrodictyon and intensive fish farming in floating nets with an addition of dry Hydrodictyon in artificial feeding.

Evolution trophique d'un réservoir aux eaux échauffées : Centre Electronucléaire de Cattenom, Moselle, France-Région Est Mots clès : Réservoir artificiel, physico-chimie, eaux échauffées, eutrophisation.

Le réservoir du Mirgenbach (Vol : 7,3 $\mathrm{Mm}^{3}, \mathrm{~S}: 90 \mathrm{ha}$, Profondeur moyenne : 7,7 m) constitue une source d'eau de sécurité et un milieu tampon pour la centrale électronucléaire de Cattenom (France-Région Est). L'eau est pornpée en rivière Moselle, filtrée, échauffée, concentrée par évaporation dans les tours de réfrigération dont les eaux de purge transitent par le réservoir en poursuivant leur refroidissement. Les eaux présentent une température, une conductivité, une dureté et une capacité d'eutrophisation plus élevées qu'en Moselle. L'étude hydrobiologique a été ef fectuée d'Avril 1986 à Décembre 1988. Avant le mois d'Août 1986, la retenue s'est comportée comme un lac de type stratifié dimictique. Dès les premières injections des eaux de purge en Août 1986, elle a évolué vers un type polymictique. Les teneurs en oxygène, la conductivité, le $\mathrm{pH}$ et la temperature sont homogènes de la surface au fond, quelles que soient la station et la date.

L'étude du niveau trophique a permis de mettre en évidence les interrelations entre les facteurs physico-chimiques et la biocénose avec ses différents niveaux trophiques. En tenant compte du niveau d'eutrophisation et de la quantité importante de biomasse produite, l'exploitation des algues et du chepte] piscicole est envisagée. Des études appliquées sont en cours, telles que l'aquaculture de l'algue verte " Hydrodictyon » et la pisciculture intensive en filets flottants avec incorporation de matière sèche algale à la ration alimentaire.

1. ENSAIA, Laboratoire d'Hydrobiologie, B.P. 172, F-54045 Vandœuvre-les-Nancy Cédex

2. Faculté des Sciences, Laboratoire d'Ecologie, 1, rue des Récollets, B.P. 4116, F-57040 Metz Cédex 01.

3. Faculté des Sciences, Nancy I, Laboratoire d'Algologie, F-54506 Vandouvre-les-Nancy Cédex. 


\section{Introduction}

Nuclear power stations are usually located alongside major rivers where reactor cooling water is readily available. The temperature of the water used for this purpose increases. The discharge of these waters back to the river may result in higher river temperatures and lower concentrations of river oxygen (Lair et al. 1980). The nuclear power station at Cattenom $(4 \times 1,300 \mathrm{MW})$ is original in being located $3 \mathrm{~km}$ from River Moselle. It was therefore necessary to create an artificial safety reservoir : « the Mirgenbach ». The lightness overheated draining waters from the cooling towers transit in this reservoir. This specific situation is of a great interest for hydrobiological studies and proposals for biomass valorization projects.

\section{Site description}

The main features of the « Mirgenbach » reservoir (fig. 1) are as follows: Volume-7.3 $\mathrm{Mm}^{3}$; area-90 ha ; mean depth-7.7 m ; elevation- $179.5 \mathrm{~m}$. Its major purpose is to serve as a safety water reserve and secondarily as a thermal buffer for the draining waters of the cooling-towers $\left(2.7 \mathrm{~m}^{3} \mathrm{~s}^{-1}\right.$ for two reactors). The mean residence time of the water is 20 days with two reactors working. There is no radioactive isotopes release in the reservoir ; they are directly mixed in the reject basin before pouring into the Moselle river. The descaling and defouling of cooling towers do not use toxic chemicals such as chlorine; there is only use of hydrochloric acid. The presence of heavy metals in connection with normal corrosion of piping will be examined separately.

The water from River Moselle is submitted to various treatments in the hydraulic circuit before reaching the cooling towers :

a) grating and filtration $(\varnothing 2 \mathrm{~mm})$;

b) overheating $\left(40^{\circ} \mathrm{C}\right)$;

c) addition of $\mathrm{HCl}$.

The lake was filled up from April to October 1985. The input of overheated waters has been effected since August 1986. The hydrobiological investigation was carried out from April 1986 to December 1988 .

\section{Methods}

Field $\mathrm{pH}$, dissolved oxygen, temperature and conductivity measurements were made using a portable multiparametric probe (VTW) along vertical and longitudinal transects at five stations (Fig. I: 1 to 5 ). Water samples were collected periodically (once or twice monthly) and analyzed for salinity, hardness, alkalinity, suspended matters, BOD. phoshorus, nitrogen compounds and silica (AFNOR standards). Water transparency was determined with a Secchi disk (Vollenweider 1974). Chlorophyll a was extracted with $90 \%$ acetone. Chlorophyll concentrations were calculated using Lorenzen's (1967) monochromatic equation. The daily rate of primary production was measured using the dissolved oxy gen method (Vollenweider 1965, Descy et al. 1987). Phytoplankton was collected with a net $(30 \mathrm{~cm}$ ill diameter, $100 \mathrm{~cm}$ de long ; mesh size $34 \mu \mathrm{m}$ ); 280 1 were filtered on an average. Zooplankton was collected with a Clarke-Bumpus automatic plankton sampler (Net $12.5 \mathrm{~cm}$ in diameter, $90 \mathrm{~cm}$ long ; mesh size $75 \mu \mathrm{m}$ ) from three depths (surface, mid-depth. near-bottom) ; 25001 were filtered on an average. The benthon was sampled at $50 \mathrm{~cm}$ depth with a benthometer $(\varnothing 30 \mathrm{~cm}$ ) in the littoral zone (B1 to B5 Fig. 1) and with artificial substrates immersed at two depths for three weeks in the central zone. Plankton (algae, Hydrodictyon excepted + bacteria + zooplankton + detritus = Albazod) and benthon biomasses were estimated by weighing alfter drying at $60^{\circ} \mathrm{C}$ in a vacuum oven for 24 hours. Fish was caught with gill nets, identified by jaw tag, and released. The estimation of population was made by the Petersen mark-recapture method (Robson \& Régie 1964).

\section{Results}

\subsection{Physical and chemical characteristics (Table I).}

The water quality is basically identical to that of the water pumped out of the River Moselle ; it has high salinity, hardness and a eutrophising capacity with overheating and a concentration of dissolved salts multiplied by 1.5 , as a consequence of evaporation in the cooling towers. These are the site of efficient cooling, outgassing, oxygenation and decantation which will have a favourable influence on the levels of temperature, $\mathrm{NH}_{4}{ }^{+}, \mathrm{NO}_{2}{ }^{-}, \mathrm{BOD}_{5}$ and COD.

The reservoir functioned as a temperate holomictic dimictic lake (Hutchinson \& Löffler 1956) before the first input in August 1986. The summer stratification started in June or July with a thermocline 


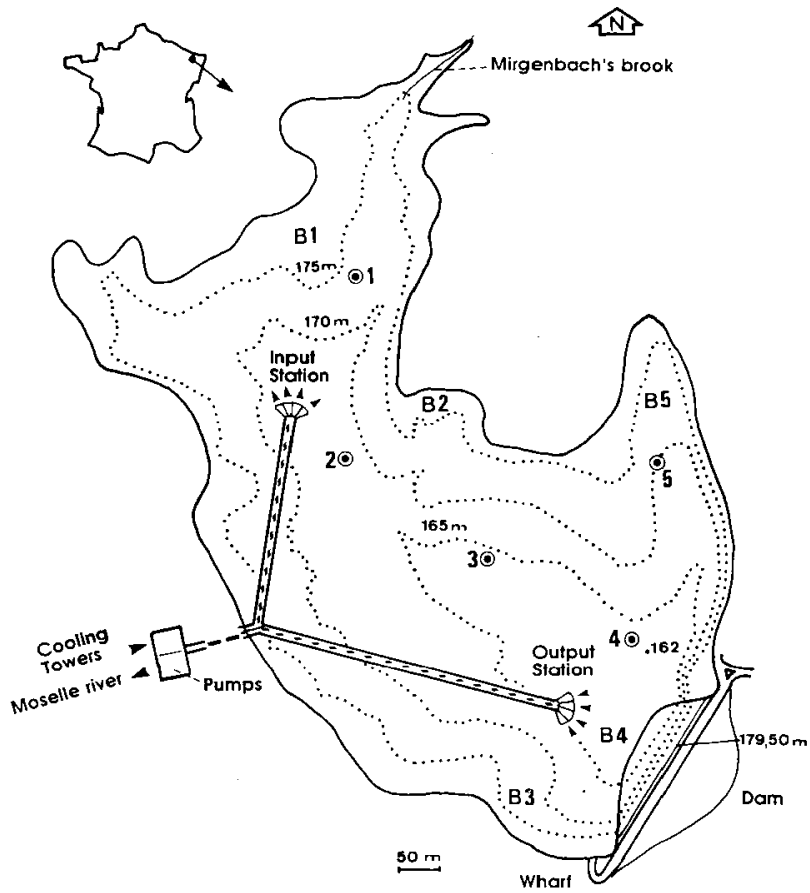

Fig. 1 : Map of « Mirgenbach $»$ Reservoir area showing sampling sites ( 1 to 5 central zone for planktonic organisms ; B1 to B5 : Litoral zone for benthic fauna).

between 5.5 and $6.5 \mathrm{~m}$, then disappeared as soon as the waters were mixed in August. Overall measurements of the temperature, the dissolved oxygen, the conductivity and the $\mathrm{pH}$ currently show homogeneity along vertical or transversal transects $(f i g$. 2 and Table I).

According to the efficiency of the cooling towers, the overtheating of the water in the Mirgenbach lake range between $+5^{\circ} \mathrm{C}$ in winter and $+1^{\circ} \mathrm{C}$ in summer in comparison with the annual distribution of temperature in the Moselle river (fig. 3).
Consequently, the water of the lake never freeze in winter and display a less overheating in summer ; in all season, the gain of temperature is proper to the biological development.

The trophic level is indicated by four major variables: Phosphorus, Nitrogen, Silica and transparency.

The phosphorus concentrations were very low in summer 1986 (total phosphorus : $4 \mu \mathrm{gP} 1^{1}$ in August, and $\mathrm{PO}_{4}{ }^{3-}$ not measurable). Then they 


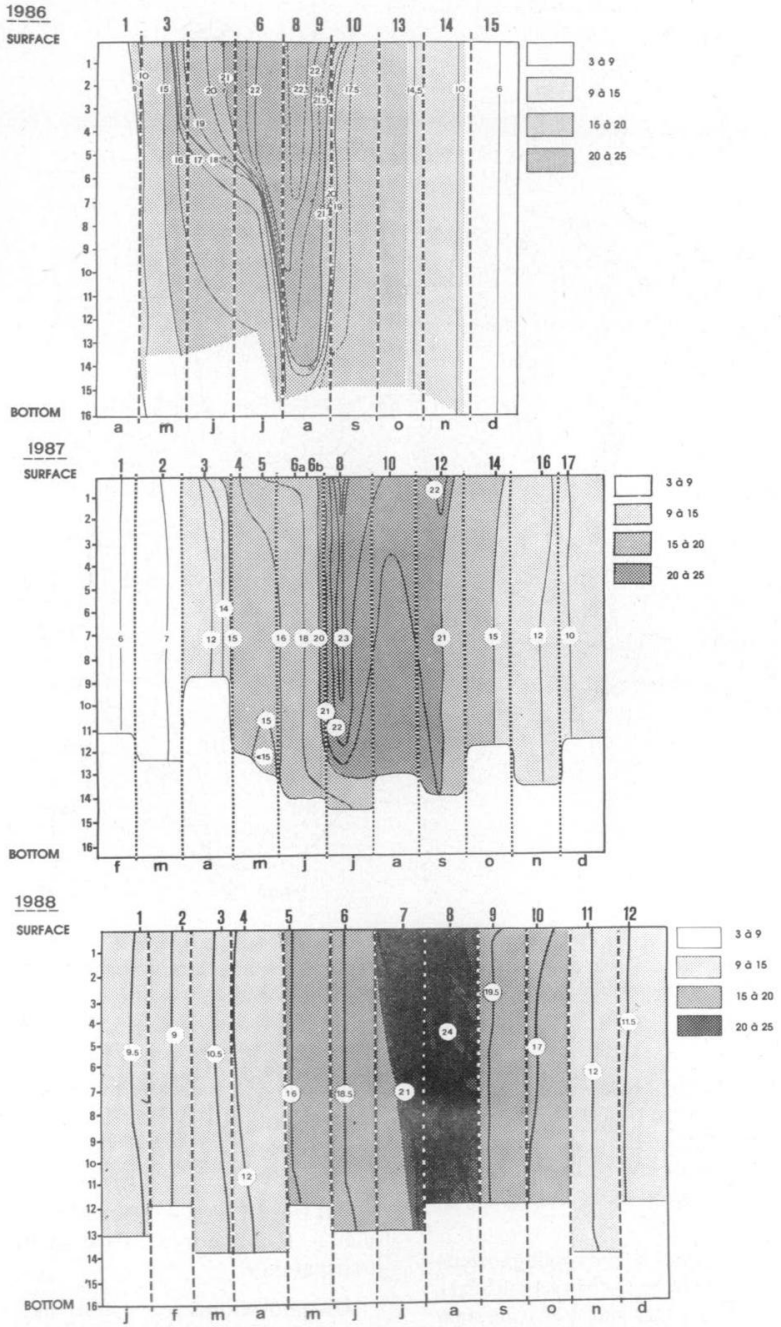

Fig. 2. Vertical isothermal profiles of «Mirgenbach Lake». History from 1986 to 1988. 
Table I : Mean ( $\overline{\mathrm{m}})$, minimum ( $\mathrm{min}$ ), maximum (max) values of physical and chemical data from 1986 to 1988 at the central station (St 3), compared to cumulate data of all stations (St 1 to St 5) in 1988 and with mean data of River Moselle at Cattenom.

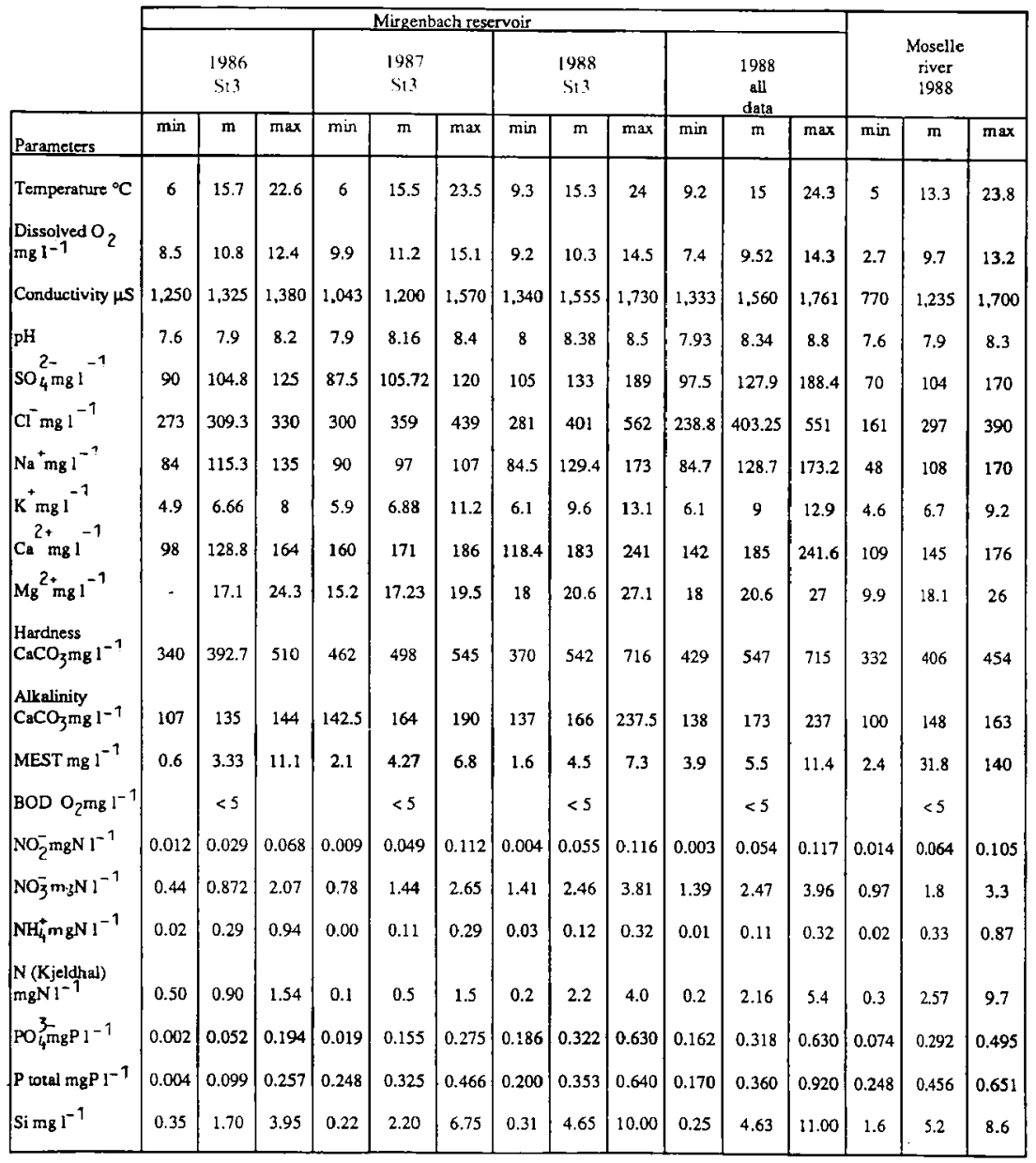




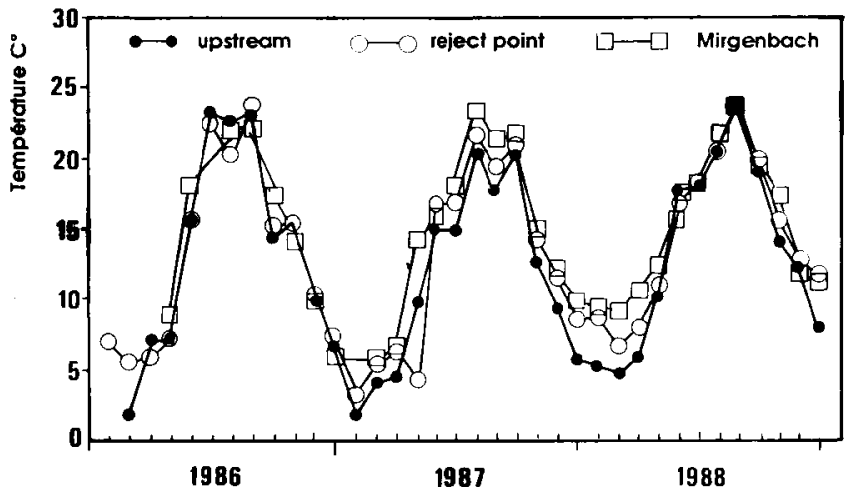

Fig. 3. Temperature profile of the Mirgenbach lake to compare with those of the Moselle river (Upstream and reject poir। ।

rose to maximal values of $630 \mu \mathrm{g} \mathrm{I}^{-1}$ in $\mathrm{PO}_{4}{ }^{3-}$ and $640 \mu \mathrm{gP} \mathrm{l}^{-1}$ in total phosphorus in 1988. The mean input from the River Moselle was $440 \mu \mathrm{gP} 1^{-1}$ in total $\mathbf{P}$.

From 1986, onwards nitrogen concentrations increased rapidly (1.80 $\mathrm{mgN}^{-1}$ in $1986,4.72 \mathrm{mgN}$ $1^{-1}$ in 1988 for total nitrogen). On an average, nitrates amounted to $60 \%$ of total nitrogen while ammonium decreased.

Dissolved silica was always present in the lake. The minimal value $\left(220{ }_{\mu} \mathrm{g} \mathrm{SiO}_{2} \mathrm{I}^{-1}\right.$ in August 1987) exceeded the amount necessary for the growth of diatoms (from 64 to $85.6 \mu \mathrm{g} \mathrm{SiO}_{2} \mathrm{I}^{-1}$ ) (Jörgensen 1957). The maximal values are $10 \mathrm{mg} \mathrm{SiO}_{2} \mathrm{l}^{-1}$ ) in winter 1988 .

The transparency has decreased regularly and considerably since 1986 . The vertical extinction coefficient (ke m ${ }^{-1}=1.76 /$ Secchi depth in $\mathrm{m}$ ) compatible with Vollenweider's data (1974) changed from $0.59 \mathrm{~m}^{-1}$ in 1986 to $1.24 \mathrm{~m}^{-1}$ in 1988 , causing a reduction of the euphotic zone from 7.8 to $3.7 \mathrm{~m}$.

\subsection{Biological characteristics and their variation}

\section{Phytoplankton dynamics}

Diatoms excepted, algae are characterized by a low diversity (about 30 taxa). Cyanophytes still represented an important part of the biomass in
1986 ; they decreased in 1987 and disappeared in 1988. Among the chlorophytes, Hydrodictyon reticulatum is particularly noteworthy. It was found only once in 1986; it appeared regularly from August to December 1987 and 1988. This biomass $\left(2.10^{5} \mathrm{~kg}\right.$ wet weight, harvested in August 1988) denote a hypereutrophication crisis. The diversity of diatoms varies from 17 to 81 taxa. The minimal values from May to September are linked to the proliferation of chlorophytes and later of Ceratium

The average annual concentration of phytoplanktonic biomass trebled from 1986 to 1987 , then stabilized to $7.32 \mathrm{mg} \mathrm{m}^{-3}$ in 1988 (Table III). Peaks in the development of the phytoplanktonic biomass could be observed from spring to autumn (Fig. 4) with maxima in July except in 1986, because of not any inflow of water from the cooling towers until August 1986 (Phosphorus becoming a limiting factor : $4 \mu \mathrm{g} \mathrm{Pl}^{-1}$ in P total).

The daily rate primary production decreased during the investigation $\left(2.57 \mathrm{gC} \mathrm{m}^{-2} \mathrm{~d}^{-1}\right.$ in 1986 , $1.78 \mathrm{gC} \mathrm{m}^{-2} \mathrm{~d}^{-1}$ in 1988).

\section{Zooplankton dynamics}

Only crustaceans were studied in the present investigation, because of their dominant contribution to biomass. Sixteen species have been identified over 


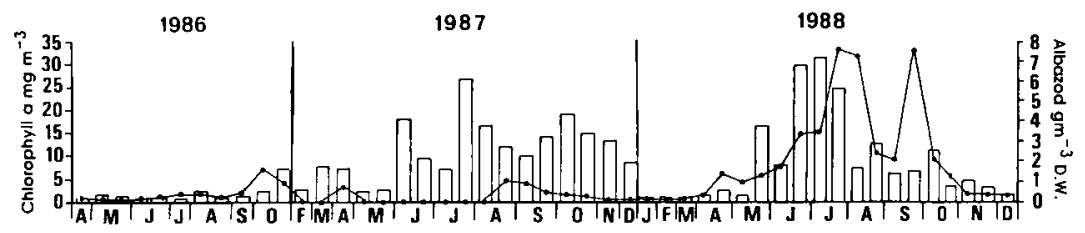

Fig. 4. Variation of phytoplanktonic (histograms) and zooplanktonic (-.-) biomasses from 1986 to 1988.

the past three years. The diversity during the peaks has varied from 5 to 11 species (with only 6 species during the second year). Five species recorded the first year disappeared : Daphnia pulex, Daphnia magna, Cyclops vicinus, Macrocyclops albidus, Eudiaptomus vulgaris. Two species were present each year with a high level of abundance : Daphnia longispina, Bosmina longirostris. Five species have developed : Thermocyclops crassus, Acanthocyclops robustus, Eudiaptomus gracilis, Diaphanosoma brachyurum, Daphnia cucullata. Four new species have appeared : Ceriodaphnia pulchella, Leptodora kindtii, Bosmina coregoni, Eurytemora velox.

In 1988, the average value of density for zooplankton at Station 3 was 11 individuals $1^{-1}$ in winter, 25 ind $\mathrm{l}^{-1}$ at the spring peak, 115 ind $\mathrm{l}^{-1}$ at the first summer peak and 220 ind $\mathrm{l}^{-1}$ at the second summer peak. The maximal density was observed between one and four meters depth with 133 ind $\mathrm{I}^{-1}$ in spring, 155 ind $\mathrm{l}^{-1}$ and 470 ind $\mathrm{I}^{-1}$ in summer.

The 1986 spring biomass (Albazod - fig. 4) was not very abundant $\left(0.2 \mathrm{~g} \mathrm{~m}^{-3}\right)$. A clear water period was followed with a modest increase at the beginning of summer $\left(0.4 \mathrm{~g} \mathrm{~m}^{-3}\right)$. The maximum development occurred in the autumn $\left(1.6 \mathrm{~g} \mathrm{~m}^{-3}\right)$, as soon as the inflow of water from the cooling towers started. In 1987, the first peak of biomass happened in Spring $\left(0.7 \mathrm{~g} \mathrm{~m}^{-3}\right.$ in April). Then the clear water period extended to late August $(0.9 \mathrm{~g}$ $\mathrm{m}^{-33}$ ).

The year 1988 was characterized by an important early spring peak $\left(1.3 \mathrm{~g} \mathrm{~m}^{-3}\right.$ in mid-April). After a short clear-water period in May, there was a regular growth until the maximum was reached in late July-August $\left(7.5 \mathrm{~g} \mathrm{~m}^{-3} ; 8.5\right.$ times the summer
1987 value). Then, a distinct decline took place in late August, beginning of September while the alga Hydrodictyon reticulatum covered the surface. After Hydrodictyon being harvested, the biomass rose again in late September $\left(7.5 \mathrm{~g} \mathrm{~m}^{-3}\right)$ then fell in autumn. In reference to 1986 , the spring and summer peaks of 1988 were respectively 6.5 and 18.75 times higher.

\section{Benthic community dynamics}

A total of 88 taxa were found during the study. The benthic fauna rose from 54 taxa in 1986 to 60 in 1988.

The structure of communities is summarized in Table II.

The stable sampling place B4 (dam) is characterized by a progressive colonization by molluscs : 14 $\mathrm{kg} \mathrm{ha}^{-1}$ in spring 1986 for a population dominated by $88,4 \%$ of chironomids. The biomass peaked with $1,290 \mathrm{~kg} \mathrm{ha}^{-1}$ in autumn 1988 , with 99,5\% molluses (Dreissena and Bythinia). The colonization of the substratum by molluscs began with pulmonate gastropods in spring and summer 1986, followed by $D$. polymorpha in winter 1987. A decreasing of the water-level at that time led to a renewed prevalence of the pulmonate gastropods in the spring and the summer of 1987 , followed by $D$. polymorpha and since the summer 1988 by Bythinia and Valvata.

Sampling place B3, on the South bank, showed important biomasses whenever gastropods (Physa and Radix) were present : in the summer of 1986 , following the growth of aquatic plants (Potamogeton and Polygonum amphibium) : in the spring and the summer of 1987 in relation to the abundance of Hydrodictyon. The very low biomass values 
Table II : Principal values of the biomass, individual and taxon values of the benthon characterizing the Mirgenbach reservoir, $m:$ mean value; $\min :$ minimum value $; \max :$ maximum value.

\begin{tabular}{|c|c|c|c|}
\hline Station & $\begin{array}{c}\text { Biomass in dry weight } \\
\text { kg ha }\end{array}$ & $\begin{array}{l}\text { Number of individuals } \\
\text { ind } \mathrm{m}\end{array}$ & Number of taxa \\
\hline B 1 & $\begin{array}{c}\bar{m}: 48.5 \\
\min : 6.24 ; \max : 183\end{array}$ & $\begin{array}{c}\dot{\mathrm{m}}: 3,256 \\
\min : 671 ; \max : 6,271\end{array}$ & $\begin{array}{c}\bar{m}: 13 \\
\min : 6 ; \max : 24\end{array}$ \\
\hline B 2 & $\begin{array}{c}\bar{m}: 23.3 \\
\min : 4.9 ; \max : 49.47\end{array}$ & $\begin{array}{c}\vec{m}: 1,462 \\
\min : 300 ; \max : 2,514\end{array}$ & $\begin{array}{c}\bar{m}: 9 \\
\min : 5 ; \max : 13\end{array}$ \\
\hline B 5 & $\begin{array}{c}\bar{m}: 30.9 \\
\min : 6.5: \max : 70.18\end{array}$ & $\begin{array}{c}\overline{\mathrm{m}}: 3,493 \\
\min : 857 ; \max : 7,742\end{array}$ & $\begin{array}{c}\bar{m}: 9 \\
\min : 3 ; \max : 15\end{array}$ \\
\hline B 3 & $\begin{array}{c}\bar{m}: 40.7 \\
\min : 1.5 ; \max : 105.8\end{array}$ & $\begin{array}{c}\bar{m}: 2,303 \\
\min : 258 ; \max : 6,258\end{array}$ & $\begin{array}{c}\overline{\mathrm{m}}: 11 \\
\min : 5 ; \max : 21\end{array}$ \\
\hline B 4 & $\begin{array}{c}\overline{\mathrm{m}}: 432.4 \\
\min : 1.4 ; \max : 1,290.18\end{array}$ & $\begin{array}{c}\bar{m}: 2,711 \\
\min : 148 ; \max : 5,960\end{array}$ & $\begin{array}{c}\bar{m}: 11 \\
\min : 7 ; \max : 21\end{array}$ \\
\hline
\end{tabular}

$6,52 \mathrm{~kg} \mathrm{ha}^{-1}$ in the autumn of 1987 and $1,5 \mathrm{~kg} \mathrm{ha}^{-1}$ in the winter of 1988 ) are due to N.W. winds which caused the disappearance of the bank sediments and aquatic plants.

In the spring 1986, the sampling places B1, B5, had a very similar structure, with a high population of Cloeon dipterum ( 70 to $89 \%$ ). They showed important fluctuations of their biomass, according to the presence or absence of gastropods : this confirms the work done by Lundbeck (1936 in Brinkhurst 1974). The accumulation of dark muds in the summer and autumn 1987 , especially in B2, caused a reduction in the biomass. In 1988, the storage of an organic muddy bottom explained the dominance of oligochaetes and chironomids, which represented from 66.6 to $96.2 \%$ of individuals. Of these three stations, $\mathrm{BI}$ was the richest, as a result of the inflow of the Mirgenbach brook, the presence of ponds near the reservoir, as well as good renewal of the water because of the westerly winds. B5 appeared as more constant, with a considerable silting with clear mud (thickness from 15 to $20 \mathrm{~cm}$ ), with little exogenous matter permitting the increase of oligochaetes $\left(7,742\right.$ ind $\mathrm{m}^{-2}$ for $70.18 \mathrm{~kg} \mathrm{ha}^{-1}$, with over $75 \%$ in number, and biomass of lumbriculids, in the autumn 1987). B2, the poorest station, was a confined area with weak currents. Decomposition of an abundant algal biomass and leaves in autumn, was taking place there ; it created very dark bottoms inhospitable to the benthon.

The structure of the benthic community showed a dual variation :

a) a disappearance or a significant decrease in the number of representative taxa living in clear waters or on aquatic plants (Hemiptera : Aphelocheirus, Gastropods : Physa, Radix).

b) a colonization by species often present in the River Moselle at Cattenom (Molluscs : Dreissena, Bythinia, Crustaceans : Atyaephyra desmarestii). 


\section{Fish population}

Eight species were caught in 1987 (perch, gudgeon, dace, roach, stone loach, rudd, barbel, pumkinseed). For the biological study of the perch, a total of 909 individuals (542 in 1987 and 367 in 1988) were caught and marked. After recapture, only perch was examined ; it represented 8 catches in 1987 and 1988 . The biomass could be evaluated to $90 \mathrm{~kg}$ $\mathrm{ha}^{-1}$ in 1987 and $120 \mathrm{~kg} \mathrm{ha}^{-1}$ in 1988.

The lake is populated with perch from 1 to 6 years old ; some of the fish must have been brought in when the lake was first filled up.

\section{Discussion and conclusion}

Several factors combine to establish, maintain and increase eutrophic conditions in Mirgenbach reservoir, including: 1) water quality of the river Moselle, strongly mineralized and eutrophicated ; 2) overheated and nutrient enriched inflow waters; 3) complete and constant vertical mixing of the water column ; 4) breaf residence time of water in the reservoir ( 20 days). There was (Table III) a variation from an oligotrophic state due to a shortage of phosphorus (1986) to a mesoeutrophic state (1987) and finally eutrophic state (1988). Hypereutrophic degradation was stopped after harvesting the green algae Hydrodictyon.

Some relationships bet ween biotic organisms and physico-chemical parameters could be established. The minimal $\mathrm{NH}_{4}$ concentrations coincided with phytoplanktonic peaks (fig. 5) and therefore, confirmed the preferential assimilation of $\mathrm{NH}_{4}$ by algae (Suttle \& Harrison 1988). The zooplanktonic biomass and the homogeneity of the water contributed to the fast mineralisation of phosphorus (Devaux et al. 1983) with, as a consequence, a high proportion of orthophosphates ( $93 \%$ of total P). The decrease in transparency was due to the phytoplanktonic biomass and the increase in dissolved elements.

As for the algal flora, an evolution from juvenile state towards maturity can be observed. The turbulence of the whole water column, noticed since 1987, justified the quasi disappearance of cyanophytes and the development of Ceratium hirundinella. According to Steinberg \& Hartmann (1988), the transfer of the surface algae to the bottom, outside the photic layer, is not favourable for cyanophytes. On the other hand, the floating green algae Hydrodictyon reticulatum can colonise the surface in association

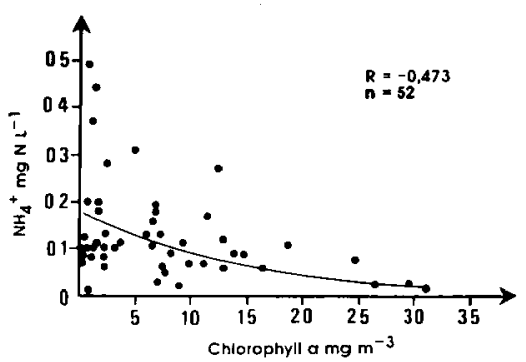

Fig. 5 . Exponential regression of the phytoplanktonic biomass (Chlorophyll a in $\mathrm{mg} \mathrm{m}^{-3}$ ) in relation to the concentration of dissolved ammonium $\left(\mathrm{NH}_{4}{ }^{+}\right.$in $\mathrm{mgN}^{-1}$ ).

with Cladophora, Oedogonium and Enteromorpha. As a secondary effect, this prevalence limits the growth of small algae by photosynthetic competition. The production rates are high in comparison with other data (Feuillade 1985) : Lake Annecy : mean 1973-76, $0.35 \mathrm{~g} \mathrm{Cm}^{-2} \mathrm{~d}^{-1}$; Lake Nantua : mean 1972-78, $0.59 \mathrm{~g} \mathrm{Cm}^{-2} \mathrm{~d}^{-1}$; Lake Geneva : mean $1972-78,0.86 \mathrm{~g} \mathrm{Cm}^{-2} \mathrm{~d}^{-1}$.

The succession of zooplankton populations can be explained by the ecology of the various species. At the time of the first filling up. D. magna, $D$. pulex and $C$. vicinus which, often present together, developed on submerged meadows (which are a source of organic matter) then disappeared when the reservoir was full. The cyclopoid $M$. albidus prefered waters with a low renewal rate. The calanoid $E$. vulgaris is known as being less resistant than $E$. gracilis to environmental variations (Cognard 1971). The permanent species are typical of an evolution from a mesoeutrophic state to an eutrophic state suitable for $D$. longispina, $D$. cucullata, D. brachyurum and $B$. longirostris. Moreover, the last three species are thermophilic or eurythermal. The coexistence of small and large species of cladocera explains the presence of carnivorous cyclopoids. $C$. pulchella is very common in shallow, eutrophic lakes, eating bacterial matter and detritus; the carnivorous $L$. kindtii will take advantage of small preys such as rotifers and crustacea. The copepod $E$. velox is an euryhaline species and therefore will benefit from 
Table III. Variation of the biomasses of the four major trophic levels from 1986 to 1988.

\begin{tabular}{|c|c|c|c|c|}
\hline \multicolumn{2}{|l|}{ Year } & $\begin{array}{c}1986 \\
\text { April to Dec. }\end{array}$ & 1987 & 1988 \\
\hline $\begin{array}{l}\text { Producers } \\
\text { Station } 3 \\
\text { Chlorophyll a } \\
\text { mg m-3 }\end{array}$ & $\begin{array}{l}\text { mean } \\
\text { minimum } \\
\text { maximum }\end{array}$ & $\begin{array}{l}3.5 \\
0.56 \\
9.3\end{array}$ & $\begin{array}{r}10.21 \\
201 \\
16.74\end{array}$ & $\begin{array}{r}7.32 \\
0.47 \\
27.93\end{array}$ \\
\hline $\begin{array}{l}\text { Primary } \\
\text { production } \\
\mathrm{O}_{2} \mathrm{~m}^{-2 d^{-1}}\end{array}$ & $\begin{array}{l}\text { mean } \\
\text { minimum } \\
\text { maximum }\end{array}$ & $\begin{array}{r}5.48 \\
0.87 \\
14.24\end{array}$ & $\begin{array}{r}5.40 \\
0.00 \\
11.39\end{array}$ & $\begin{array}{l}3.79 \\
0.05 \\
8.14\end{array}$ \\
\hline $\begin{array}{l}\text { Transparency } \\
\text { in } m \text { (Secchi) }\end{array}$ & $\begin{array}{l}\text { mean } \\
\text { minimum } \\
\text { maximum }\end{array}$ & $\begin{array}{l}3.86 \\
1.42 \\
6.31\end{array}$ & $\begin{array}{l}1.64 \\
1.12 \\
3.12\end{array}$ & $\begin{array}{l}1.89 \\
0.73 \\
4.40\end{array}$ \\
\hline $\begin{array}{l}\text { Planktonic feeders } \\
\text { Albazod } \mathrm{mg} \mathrm{m}^{-3} \text { (dry } \\
\text { in the central area }\end{array}$ & & & & \\
\hline $\begin{array}{l}\text { Surface } \\
\text { between } 0.5 \mathrm{~m}\end{array}$ & $\begin{array}{l}\text { mean } \\
\text { minimum } \\
\text { maximum }\end{array}$ & $\begin{array}{r}719 \\
18 \\
4,790\end{array}$ & $\begin{array}{r}209.4 \\
3.5 \\
981.8\end{array}$ & $\begin{array}{r}2.150 \\
52 \\
7,560\end{array}$ \\
\hline $\begin{array}{l}\text { Mid depth } \\
\text { between 5-10 m }\end{array}$ & $\begin{array}{l}\text { mean } \\
\text { minimum } \\
\text { maximum }\end{array}$ & $\begin{array}{r}400 \\
91 \\
1,600\end{array}$ & $\begin{array}{r}169.5 \\
3.5 \\
900.9\end{array}$ & $\begin{array}{r}3,130 \\
107 \\
18,829\end{array}$ \\
\hline $\begin{array}{l}\text { Near bottom } \\
\text { between } 10-15 \mathrm{~m}\end{array}$ & $\begin{array}{l}\text { mean } \\
\text { minimum } \\
\text { maximum }\end{array}$ & $\begin{array}{r}363 \\
15 \\
1,540\end{array}$ & $\begin{array}{r}194.6 \\
1.7 \\
928.5\end{array}$ & $\begin{array}{r}3,230 \\
109 \\
14,285\end{array}$ \\
\hline $\begin{array}{l}\text { Benthic feeders I a } \\
\mathrm{kg} \mathrm{ha} \mathrm{a}^{-1} \\
\text { for the } 5 \text { stations }\end{array}$ & & & & \\
\hline Winter & $\begin{array}{l}\text { mean } \\
\text { minimum } \\
\text { maximum }\end{array}$ & $\begin{array}{c}\text { no data } \\
\text { "1 }\end{array}$ & $\begin{array}{c}57.24 \\
3.2 \\
244.7\end{array}$ & $\begin{array}{r}37.5 \\
1.5 \\
108.6\end{array}$ \\
\hline Spring & $\begin{array}{l}\text { mean } \\
\text { minimum } \\
\text { maximum }\end{array}$ & $\begin{array}{r}21.5 \\
1.4 \\
49.1\end{array}$ & $\begin{array}{l}97.12 \\
49.4 \\
183\end{array}$ & $\begin{array}{r}240.3 \\
13.5 \\
1,087.5\end{array}$ \\
\hline Summer & $\begin{array}{l}\text { mean } \\
\text { minimum } \\
\text { maximum }\end{array}$ & $\begin{array}{r}28.4 \\
6.5 \\
86.3\end{array}$ & $\begin{array}{l}39.5 \\
15.8 \\
93.1\end{array}$ & $\begin{array}{r}271.16 \\
4.9 \\
1,235.4\end{array}$ \\
\hline Autumn & $\begin{array}{l}\text { mean } \\
\text { minimum } \\
\text { maximum }\end{array}$ & $\begin{array}{l}35.34 \\
13.2 \\
64.4\end{array}$ & $\begin{array}{r}755 \\
6.5 \\
281.6\end{array}$ & $\begin{array}{r}276.1 \\
11.9 \\
1,209.7\end{array}$ \\
\hline $\begin{array}{l}\text { Fish } \\
\text { (Perca fluviatilis) } \\
\text { Biomass in kg ha }\end{array}$ & & no data & 90 & 120 \\
\hline
\end{tabular}


a salinity increase. The prevalence of cladocerans $(83,3 \%$ in spring and $61,2 \%$ in summer $)$ over calanoids and cyclopoids enables us to set this reservoir in « class 5 " of the typology of Bressac (1985).

If the eutrophication increases even more, the calanoids may disappear (Lair 1975, Janiki et al. 1979, Bressac 1982). The structure of the fish population has an impact on the zooplanktonic one ; the predominance of ichtyophagous fish (Perca fluviatilis) as compared to planktonophagous fish accounts for the abundance of large size zooplanktonic species (D. longispina, D. brachyurum, Calanoids) with an high grazing rate on phytoplankton. The carnivorous species $(C$. vicinus, $L$, kindtii) eat the smaller cladocera ( $B$. longirostis, $C$. pulchella) the filtering organic matter and associated decomposers (Bacteria and Protozoa).

By comparing with other values $\left(600\right.$ ind $1^{-1}$ in Créteil reservoir, Testard 1983), the lower density of zooplankton can be explained by the fact that the outflow $\left(2.7 \mathrm{~m}^{-3} \mathrm{~s}^{-1}\right)$ carries away part of the zooplankton whereas the inflow $\left(2.7 \mathrm{~m}^{3} \mathrm{~s}^{-1}\right)$ brings none. Bressac (1985) thinks that this applies to the Serre-Ponçon reservoir in which the lowest density is 55 individuals $1^{-1}$. Despite the overheating, a seasonal rhythm in the dynamics of populations is appearing : a peak in spring explaining the clear water period, because of the grazing by smaller zooplanktonic species; a higher peak in summer, a decline in autumn and a minimum level in winter. Contrary to what is reported in the literature (Grégoire 1981, Pinel Alloul \& Méthot 1984), no demographic explosion occurred after the first filling, because of phosphorus deficiency due to its incorporation in the biomass.

The maximum benthic biomasses (excluding the dam) can be compared with those of the literature. Bouchaud et al. (1979) found $122 \mathrm{~kg} \mathrm{ha}^{-1}$ in the lower section of a gravel pit in the River Loire. Testard (1983) gave 44.19 and $53.33 \mathrm{~kg} \mathrm{ha}^{-1}$ for the mesoeutrophic Créteil lake, according to the substratum, whereas for eutrophic lakes, the littoral benthic fauna reaches $330 \mathrm{~kg} \mathrm{ha}^{-1}$ (Morgan 1980) and $10.3 \mathrm{~kg} \mathrm{ha}^{-1}$ of dry weight without shells in Lake Simcoe (Rawson 1930). The mean population (from 1,500 to 3,500 individuals $\mathrm{m}^{-2}$ ) is much lower than that of the littoral samples of Lake Saint-Louis (Quebec) $\left(7,500\right.$ individuals $\left.\mathrm{m}^{-2}\right)$ which is said to be in an advanced eutrophication state (Magnin
1970). Our results, which are significantly different, show that the Mirgenbach reservoir is in trophic variation.

In the specific case of the dam, although the number of $D$. polymorpha decreases from 1,800 to 650 ind $\mathrm{m}^{-2}$, their biomass inereases from 240 to 1,025 $\mathrm{kg} \mathrm{ha}^{-1}$ of dry weight, including shells. The values for this species (biomass/population) are comparable with those observed in eutrophic Mazurian Lakes (Stanczykowska 1977). Stanczylowska (1984) established the absence of such molluses in polymictic type IV lakes (Total phosphorus from 300 to 950 $\mu \mathrm{g} \mathrm{l}$ '), whereas we showed that these molluscs are represented in the Mirgenbach Lake. This calls for an investigation of the evolution of $D$. polymorpha, which is also a prey to crayfish (Orconectes limosus) (Piesick 1974 in Stanczykowska 1977) ; water owls (Pedroli 1981) ; coot (Fulica atra), tuffed duck (Aythya fuligula), pochard (Aythya ferina) and mallard (Anas platyrhynchos) of which 2,000 to 2,500 individuals are living on the lake in winter.

To explain the decreasing diversity of fish two hypotheses can be put forward : a) the species of fish - other than perch - have slowly disappeared because they were not adapted to the biotope ; for instance, dace is known to prefer fast currents. b) the species have declined because of the strong predation by perch.

It is known that a monospecific population of perch may disrupt the balance of the environment and can cause nanism (Hoestlandt 1979). Consequently, we decided to intervene by stocking the reservoir $\left(17 \mathrm{~kg} \mathrm{ha}{ }^{-1}\right)$ with omnivorous species (Cyprinus, Tinca) and great carnivorous fish (Esox, Lucioperca) ; the former to limit the propagation of large zooplanktonic species, and the latter because of their ability of regulating the population of Perca. According to the available bibliographical data (Angeli 1976, Pourriot et al. 1982), we can expect the small zooplanktonic species (Rotifera, Bosmina, Ceriodaphnia) to develop. Consequently, the intensity of grazing should decline resulting in diminished lakewater transparency for longer periods. This evolution should keep the proliferation of Hydrodictyon down. As an alternative, aquaculture of these algae is being planned. The harvest of these algae will be an appropriate method to restrain the hypereutrophication (Laurent 1976). Fish farming in floating nets could also be developed using herbivorous species able to eat dry 
Hydrodictyon incorporated into an artificial diet. The purpose of this programme is to take advantage of the waters from the cooling towers. It can be implemented taking all the environmental issues into account : the physical and chemical variations of the water quality, the qualitative and quantitative variations of the trophic chain.

\section{Aknowledgements}

The authors wish to express their thanks to E.D.F. This work was carried out for project in hydrobiological studies, in agreement with the Nuclear Power Station at Cattenom, France.

\section{References}

Angeli (N.). 1976. - Influence de la pollution des eaux sur les elements du plancton. In Pesson (P.). La pollution des eaux continentales, Gauthier-Villars éd., Paris : 97-133.

Bouchaud (B.), Clavel (P.), Hamon (Y.) \& Romaneix (C.). 1979. - Incidences des extractions de matériaux alluvionnaires et de l'aménagernent des cours d'eau sur l'écosystème aquatique. Bull. fr. Piscic., 273 : 137-156.

Bressac (Y.). 1985. - Le zooplancton des lacs de barrage. Les tetenues du Sud-Est de la France. Influence des arrivées d'eau et de la qualité du seston sur la structure spatiale du peuplement. Thèse Doct. ès Sci., Univ. de Provence : 144 pp.

Brinkhurst (R.O.). 1974. - The benthos of lakes. MC Millan Press ad. : $190 \mathrm{p}$

Cognard (Cl.). 1971. - Etude écologique de deux espèces de Copépodes Calanoìdes du genre Eudiapiomus. Influence de la température sur le développement de $E$. gracilis. Thèse 3ème cycle. Univ. Orléans : $95 \mathrm{p}$.

Descy (J.P.), Servais (P.), Smitz (J.S.), Billen (G.) \& Everbecq (E.). 1987, - Phytoplancton biomass and production in the river Meuse (Belgium). Wat. Res, 21 (2) : 1557-1566.

Devaux (A.), Lair (N.) \& Amblard (C.). 1983. - Un écosystème lacustre profond : le lac Pavin. In Lamotte (M.) \& Bourlière (F.). Problèmes d'écologie. Ecosystèmes limniques. Masson éd., Paris : 1-49.

Feuillade (J.). 1985. - Caractérisation et essais de restauration d'un ecosystème dégradé : le lac de Nantua. INRA éd., Paris : $165 \mathrm{p}$.

Grégoire (A.). 1982. - Contribution à l'étude hydrobiologique d'une rivière aménagée: le Verdon (Alpes de HauteProvence). Les lacs de barrage et les tronçons de cours d'eau à débit régulé. Cahiers du Laboratoire d'Hydrobiologie de Montereau, France, 13:172 p.

Hoestlandt (H.). 1979. - Le nanisme de la perche en France est-il un mythe? Bull. Cont. Etud. Rech. Sci. Biarritz, France, $12: 453-470$.

Hutchinson G.E.) \& Loffler (H.). 1956. - The thermal classification of lakes. Proc. natl. Acad. Sci. Wash., 42 : 84-86.

Janicki (A.), De Costa (J.) \& Davis (J.). 1979. - The midsum. mer crustacean plankton communities of seven small impoundments. Hydrobiologia, 64 : 122-129.

Jörgensen (E.G.). 1957. - Diatom periodicity and silicon assimilation. Dansk Bot. Arkiv, $18: 10-64$.

Lair (N.). 1975. - Rôle du zooplancton dans les réseaux trophiques de deux lacs du Massif Central français. Thèse Doct. ès Sc, Univ. Clermont-Ferrand : $166 \mathrm{p}$.
Lair (N.), Nourisson (J.M.) \& Pihan (J.C.). 1980. - Conception et principaux résultats des études hydrobiologiques effectuées sur différents sites electronucléaires. Rev. genn. Elect., I 31-44.

Laurent (P.). 1976. - L'eutrophisation des lacs. Détectio. remedes. In Pesson (P.). La pollution des eaux continentules, Gauthier-Villars éd., Paris : 89-96.

Lorenzen (C.J.). 1967. - Determination of chlorophyll and pheopigments : spectrophotometric equations. Limnol. Oceanogr., $12: 343-347$.

Magnin (E.). 1970. - Faune benthique littorale du lac SaintLouis près de Montréal (Québec). Ann. Hyarobiol., 1 : 179-193.

Morgan (N.C.). 1980. - Secondary production. In Le Cren (E.D.) \& Lowe (R.H.), Mc Connell. The functioning of freshwater ecosystems. Cambridge University Press, Cambridge : 247-340.

Pedroli (J.C.). 1981. - Les relations entre la moule zébrée ( $D$. polymorpha Pallas) et les oiseaux aquatiques. Thèse Faculté des Sciences de Neufchâtel : $92 \mathrm{p}$.

Pinel-Alloul (B.) \& Methot (G.). 1984, - Preliminary study of the effects of impoundments of LG-2 reservoir (James bay Territory, Quebec) on the net seston and the zooplankton of impounded rivers and lakes. Int. Revue ges. Hydrobiol. , 69 : 57-78.

Pourriot (R.), Capblancq (J.), Champ (P.) \& Mcyer (J.A.). 1982. - Ecologie du plancton des eaux continentales. Collection d'Ecologie 10. Masson éd., Paris : $198 \mathrm{pp}$.

Rawson (D.S.). 1930. - The bottom fauna of lake Simcoe and its role in the ecology of the lake. Univ. Toronto Studies. Publ. Ont. Fish, Res, Lab., 40:183 p.

Robson (D.S.) \& Régier (H.A.). 1964. - Sample size in Petersen mark-recapture experiments. Trans. am. Fish. Soc., 93 : 215.232.

Stanczylowska (A.) 1977. - Ecology of Dreissena polymorpha (Pall.) (Bivalvia) in lakes. Pol. Arch. Hydrobiol, 24 : 461-530.

Stanczylowska (A.). 1984, - The effect of various phosphorus loadings on the occurence of Dreissena polymorpha (Pall.). Limnologica (Berlin) 15 : 535-539.

Steinberg (C.) \& Hartmann (H.). 1988. - Planktonic bloomforming Cyanobacteria and the eutrophication of lakes and rivers. Freshwat, Biol. $20: 279-287$.

Suttle (C.A.) \& Harrison (P.J.). 1988. - Ammonium and phosphate uptake rates, $\mathrm{N}: \mathrm{P}$ supply ratios and evidence for $\mathrm{N}$ and $\mathbf{P}$ limitation in some oligotrophic lakes. Limnol. Oceanogr., $32: 186-202$

Testard (P.). 1983. - Le lac de Créteil (R.P.). Un lac de sablière peu profond. In Lamotte (M.) \& Bourlière (F.). Ecosysteme limniques. Masson éd., Paris : 113-159.

Vollenweider (R.A.). 1965. - Calculation models of photosynthesis depth curves and some implications regarding day rate estimates in primary production measurements. Me. Ist. Itol. Idrobiol., 18 suppl. : 425-457.

Vollenweider (R.A.). 1974, - A manual on methods for measuring Primary Production in aquatic environments. Second edition. Blackwell Scientific Publications, Oxford : 225 p. 